\title{
Determination of Hydrogeological Characteristics by Mikala 2 Well Pumping Test In The Commune of N'sele / Kinshasa R.D.Congo
}

\section{Rally KIMPESE TALONG ${ }^{14}$, Rais SEKI LENZO ${ }^{134}$, Grady KALONJI LELO ${ }^{1}$, Louis MUDJINDJI IKOMBA ${ }^{24}$, Hugues MAKIMA MOYIKULA ${ }^{145}$}

${ }^{1}$ Faculty of Oil, Gas and New Energies, Department of Exploration and Production, University of Kinshasa, DR Congo

${ }^{2}$ Faculty of Agronomic Sciences, Department of Natural Resources Management, University of Kinshasa, DR Congo

${ }^{3}$ Centre de Recherche en Géophysique (C.R.G), Department of Internal Geophysics, Kinshasa, DR Congo

${ }^{4}$ Laboratory for Hydraulic Development and Energy Production Engineering (LAH-IPE), University of Kinshasa, DR Congo

${ }^{5}$ National Center for Remote Sensing (CNT), Kinshasa, DR Congo

\begin{abstract}
This work is of particular interest in the field of rational and sustainable management of water wells since the study of the capacity of the aquifer makes it possible to know the quantity of water that can be taken from the tablecloth, so as not to lead to its exhaustion. The hydrogeological characteristics obtained also make it possible to understand the capacity of the aquifer to react to its drainage by wells or to natural drainage by rivers in its hydrogeological watershed or to its water supply.

The objective of this work is to determine the best hydrogeological method, the hydrogeological characteristics of the aquifer that feeds the Mikala 2 well in the municipality of Nsele. These are the transmissivity, the hydraulic conductivity, the storage coefficient and the diffusivity coefficient of the water table in the municipality of Nsele.
\end{abstract}

Keywords: Hydrogeology, Aquifer, Transmissivity, Storage coefficient, Diffusivity.

\section{INTRODUCTION}

The absence of a drinking water distribution network in many communes in the city of Kinshasa creates serious health, social, hygienic and environmental problems.

To solve this problem of water need in the city of Kinshasa, it would be necessary to think of the installation of the new water treatment and distribution units. This means revolutionizing the financial and technical status of REGIDESO (the body responsible for the distribution of drinking water). Exploitation of groundwater could be considered as an alternative, since the exploitation of groundwater resources is easy and inexpensive with less investment.

In the municipality of Nsele, one of the municipalities where there are no REGIDESO water distribution works, we are witnessing strong population growth and the multiplication of water boreholes. So the assessment of the capacity of the aquifer in this commune of the city of Kinshasa is very important.

Pumping tests are a very important means in a water supply project since they make it possible to judge whether the work carried out meets the objectives set. They determine how much water can be pumped, how often, which pump to choose and how deep to install it.

Thus pumping tests constitute an essential tool for the assessment and the quantitative as well as qualitative management of groundwater resources in this part of the city of the city of Kinshasa. It is in this context that this study conducted in the city of Kinshasa, more particularly in the commune of Nsele, takes place.

So we ask ourselves the questions of knowing:

- How does the water table react to excessive water extraction?

- How much water is the aquifer capable of giving to the population of the commune of Nsele? 
International Journal of Advances in Scientific Research and Engineering (ijasre), Vol 6 (2), February-2020

The pumping test can provide information on the characteristics of the Nsele aquifer, making it possible to design a drinking water supply project for the municipality.

\section{MATERIAL AND METHOD}

\subsection{Method}

During this study the following methods were used:

- Documentary research: which enabled the development of the general framework and the geology of the city of Kinshasa; and general information on pumping tests;

- $\quad$ Pumping test method: for determining the hydrogeological characteristics of the aquifer.

\subsection{Material}

- $\quad$ A stopwatch: for recording the time of the water depth;

- $\quad$ A GPS (global positioning system): it is an advanced device which makes it possible to give the exact position (in 3 dimensions: latitude, $\mathrm{x}$; longitude, $\mathrm{y}$ and altitude, $\mathrm{z}$ ) of the place at which where you are and where you performed the pumping test;

- A probe: it is a device that measures the depth of the surface of the water in a well;

- $\quad$ Microsoft office Word and Excel for data entry and various graphics.

\section{GENERAL FRAMEWORK AND GEOLOGY OF KINSHASA}

\subsection{Surface and population}

The city of Kinshasa has an area of 9,965 km2. However, the city itself or the urbanized part is much smaller. Currently, the urbanized area of the city is approximately $650 \mathrm{~km} 2$ compared to $600 \mathrm{~km} 2$ in 1985, $134 \mathrm{~km} 2$ in 1955 and $20 \mathrm{~km} 2$ in 1950 . There has been constant general population growth and spatial expansion. However, two periods were marked by remarkable population growth rates:

- The first took place from 1941 to 1948 , a period during which the population of Kinshasa tripled thanks to economic prosperity during and after the second world war.

- $\quad$ The second demographic surge occurred after independence in 1960.

Most Kinois are very young, as one would expect from the low life expectancy of 53.29 years and the high population growth rate of 3.39 (high fertility). More than half of the population is under 20 years of age. Some reports indicate that today, half of Kinshasa's population is under the age of 15. The birth rate is higher in Kinshasa (51.1 per 1000) than in the other regions of the Congo (48.1 per 1000). This is associated with a lower mortality rate than that of other Congolese cities [7].

\subsection{Socio-urban framework}

At the beginning of the colonial period, the small town of Léopoldville had well-defined ethnic-urban divisions:

- North European area where administration, commerce and industry were concentrated (Europeans also had residential villas on the hill of Ngaliema and the hills of South and South-West of Binza and Djelo);

- A transition zone or a narrow buffer zone occupied by the Portuguese who were small traders;

- The southern zone intended for the natives who supplied the labor and lived in planned neighborhoods of residence called "indigenous cities".

At present, the city is made up of 24 communes which can be divided into three socio-urban areas.

- The "City" or "Centerville" to European urbanization inherited from colonization. It is the region where the colonizer lived and worked during the colonial era and which is today the privileged sector where the elite lives. It is also the commercial and administrative heart of the city. It stretches from the hill of Ngaliema in the west to the Malebo basin in the east. The Congo River is the northern limit. This area is crossed, in an east-west direction, by the main artery of the city: the boulevard du 30 juin. The city includes the municipalities of Gombe, Barumbu, Kinshasa and Lingwala, as well as the northern tip of the municipalities of Bandalungua and Kintambo

The City or the working-class district. It is located south of the city and includes most of Kinshasa where most of Kinois lives, at low income. It carries all the elements of Aboriginal culture, art and cuisine. It is separated from the rich center of the North by the government and industrial green belt. The main artery in this area is Kasa-Vubu Avenue, which runs from north to south and southwest. Originally, in colonial times, the "native cities" that occupied this area were planned living spaces. However, later, this 
area degenerated into a slum situation. Administratively, the area covers the municipalities of Bandalungwa, Kintambo (except the northern points), Ngaliema, Selembao, Bumbu, Ngiri-Ngiri, KasaVubu, Kalamu, Makala, Lemba, Ngaba, Limete, Matete and Masina.

- The third socio-urban area of Kinshasa is made up of outlying cities, urban and rural communities, or shanty towns. These occupy large areas on the hills of the South and the plain of the east and extend over the municipalities of Mount Ngafula, Kinsenso, Ndjili, Kimbanseke and Nsele. They are a symbol of the unplanned chaotic spatial growth of Kinshasa. They lack basic infrastructure and urban services. Here, a large number of Kinois live outside the formal urban area of Kinshasa [7].

\subsection{Urban ecology}

\subsubsection{Climate and vegetation}

The climate is tropical Sudanese or Sudano-Guinean. The city has two main seasons:

- A wet season which extends from October to May with hot temperatures $\left(25.6^{\circ} \mathrm{C}\right)$;

- A dry season which extends from June to September with slightly cooler temperatures $\left(22.8^{\circ} \mathrm{C}\right)$ [14].

The slight temperature difference between the seasons indicates a relative isothermal climate. A drier period (15 days) was recorded during the rainy season (end of December). The average relative humidity is $79 \%$ (between $71 \%$ minimum and $84 \%$ or more maximum). The average annual rainfall is $1529 \mathrm{~mm}$ (with a minimum of $1222 \mathrm{~mm}$ and a maximum of $1863 \mathrm{~mm}$ ). Heavy torrential rains occur in November, immediately after the dry season, as well as in March and April. A grassy vegetation develops. The type of soil and the humidity conditions allow the growth of a typical shrubby savannah (species of herbaceous xerophiles) and an oily vegetation similar to that of a tree [14].

\subsection{Geological context}

The Kinshasa region is located east of the Pan-African belt in western Congo. Based on geological reconstructions, it appears that from a tectono-stratigraphic point of view, the Kinshasa region is part of a basin of the hinterland after the Pan-African orogeny. The few folds and pleated faults (Schisto-Limestone sequence) in the southwest of the province of Kinshasa (for example, the locality of Bamba Kilenda) plunge into the Kinshasa region, under siliclastic sediments of Inkisi slightly inclined towards the Northeast and covering young continental sediments. The geological framework of the city of Kinshasa has developed in a transition zone between two geologically opposite domains:

- In the West, downstream of the Ngaliema basin and further downstream of the basin, the siliciclastic sedimentary rocks of the Inkisi group (Frimmel et al, 2006), called Kinsuka arkoses, subhorizontal slightly inclined towards the Northeast, begin to be exposed and impose the first rapids or cataracts on the Congo River. From there, the river flows in a gorge about $500 \mathrm{~m}$ wide, facing southwest, dug in the red beds of Inkisi. The rocks have a very visible, subvertical joint, oriented northeast and northwest. They are found discordantly above generally cemented sandstone from the Upper Cretaceous sandstone, Kwango series, generally poorly consolidated, forming a chain of rather flat hills (approximately $500 \mathrm{~m}$ ), with slightly degraded inter-course stretches and wide inactive valley [18].

- In the East, near the locality of Maluku and upstream of the swimming pool, the exposed part consists (from bottom to top) in white sands of the Cretaceous (Kwango series), generally consolidated and forming along the most northeast part of the pool. The so-called Dover Cliffs. These sand sequences are covered by the Cenozoic sequences of the Kalahari, including the Paleogene sands, locally strongly solidified in ortho quartzite plates (Polymorphic Sandstones), covered with loose loose sands (Ocher Sands). The latter forms a flat, located at around 700 meters above sea level and presenting an exceptional microrelief.

\subsubsection{Local stratigraphy}

The stratigraphy of the Kinshasa region was developed over 50 years ago [6]. No stratigraphic revision or age has been introduced in the past five decades. We must therefore be aware of the constraints on the level of knowledge.

All the deposits are continental of fluvial, fluviodeltaïc, fluviolacustrine, lacustrine and wind genesis. Kinshasa's documented stratigraphy ranges from the Upper Precambrian to the Holocene, with many discrepancies of different magnitudes. The litho stratigraphy of the city of Kinshasa is given in Figure I.3. It is part of the stratigraphy of the largest province of Kinshasa. 


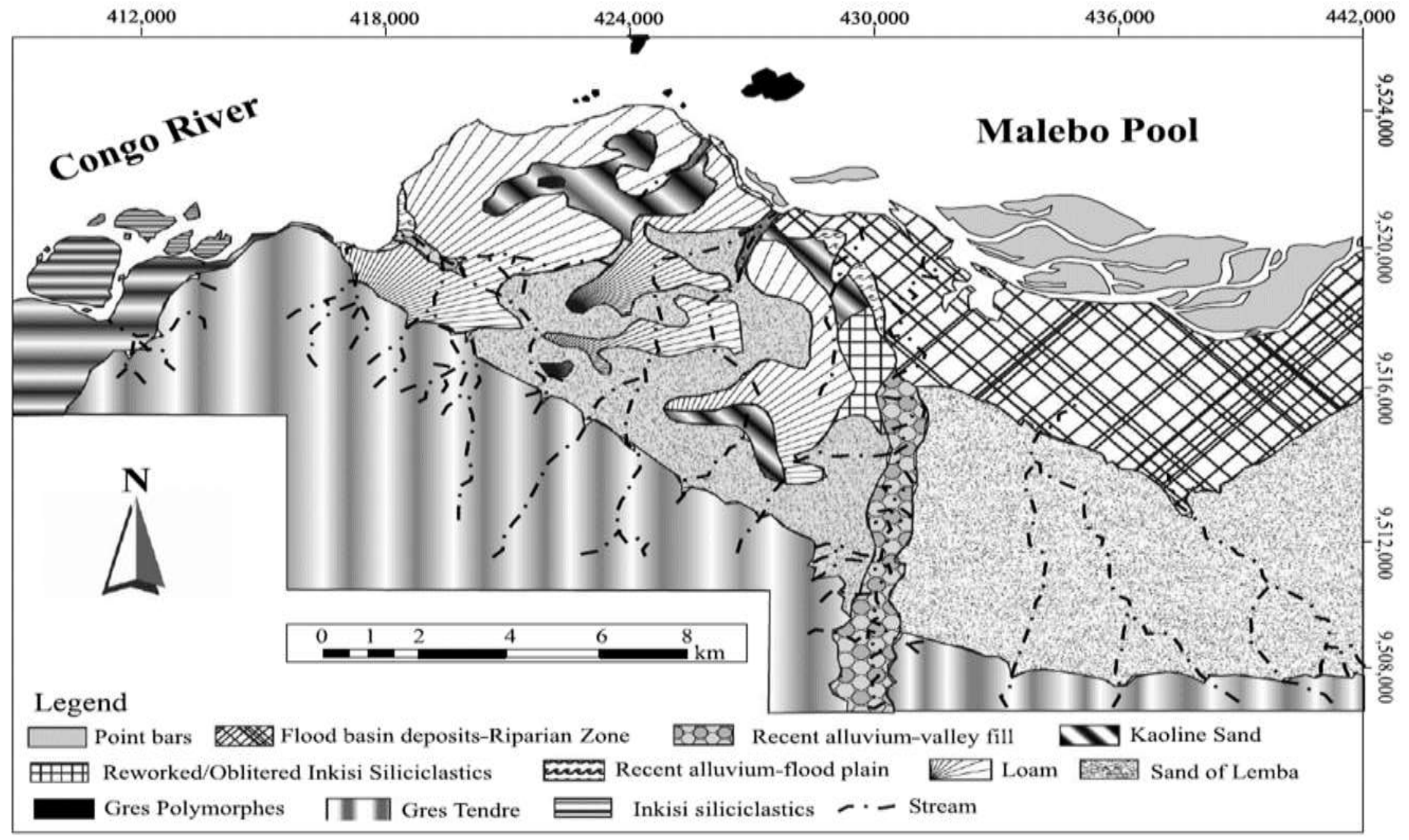

Figure 1.4.1: the geological map of the city of Kinshasa [1]. 


\section{RESULT AND DISCUSSION}

This chapter is based on the presentation and interpretation of the various results collected in the field. It is based on different pumping tests and interpretation.

\subsection{Presentation of data}

Certain data that we use in this work, were provided to us by the national company of rural hydraulics (SNHR)

\subsubsection{The presentation of the well and the lithological section}

The Mikala 2 well located in the municipality of Nsele was drilled on May 04, 2014. It has a total depth of $111.5 \mathrm{~m}$, with an internal diameter of $200 \mathrm{~mm}$.

Table 3.1.1: the presentation of the Mikala 2 well (SNHR)

$\begin{array}{lll}\text { Disposition } & \text { Diameter } & \text { Thainer (m) }\end{array}$

From To

Aboveground

$0 \quad 36 \quad 200$

$\begin{array}{llll}36 & 60 & 200 & 24\end{array}$

$\begin{array}{llll}60 & 85 & 200 & 23\end{array}$

$\begin{array}{lllll}85 & 100 & 200 & 8 & 15\end{array}$

$100 \quad 111,5 \quad 200 \quad 11,5$

$\begin{array}{lll}\text { Total } & 31 & 111,5\end{array}$

Electromechanical Pedrollo poxer pump 4 kw/ Generator $30 \mathrm{KVA}$

The lithological column crossed by the Mikala 2 well is presented as follows according to the depth:

- $\quad$ From 0 to $2 \mathrm{~m}$ : blackish sandy silt;

- $\quad$ From $2 \mathrm{~m}$ to $5 \mathrm{~m}$ : reddish clay;

- $\quad$ From $5 \mathrm{~m}$ to $20 \mathrm{~m}$ : fine yellowish clay sand;

- $\quad$ From 20m to 35m: whitish sand;

- From 35m to 40m: Whitish quartzite;

- $\quad$ From 40m to 45m: The yellowish polymorphic sandstone;

- $\quad$ From 45m to 60m: Whitish Kaolinite;

- $\quad$ From $60 \mathrm{~m}$ to $85 \mathrm{~m}$ : The sand whitish whitish;

- $\quad$ From $85 \mathrm{~m}$ to $100 \mathrm{~m}$ : Soft reddish sandstone;

- $\quad$ From 100 to 111.5: Reddish and blackish inkisi sandstone. 
PROVINCE DE KINSHASA
SITE DE MIKALA $2(111.5 \mathrm{~m})$

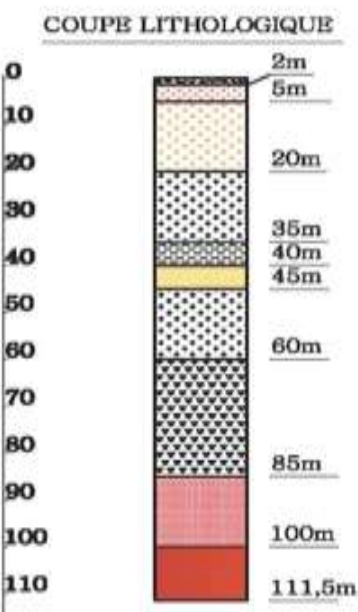

COUPE TECHNIQUE

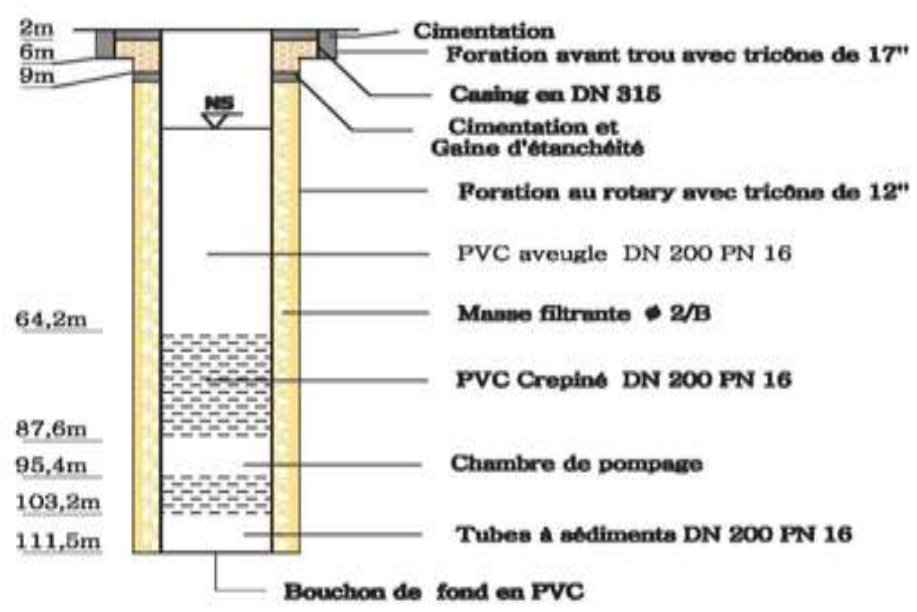

Larende

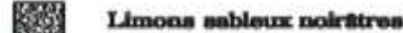

Argilon rougoetine

Sable fin mrulloux jaunatroe

83 Sable a moyen blanchatreo

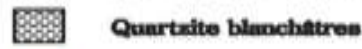

$\square$ Gron de polymorphes jeunatirea

Kaolinite Blanchâtre

兹学 Sable grossier blanchâtre

$\square$ Grib tendro rougeative

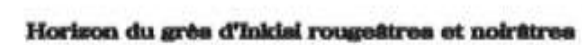

Porage : Prof foree
Niveau stat $\quad \begin{gathered}111,5 \mathrm{~m} \\ 19,8 \mathrm{~m}\end{gathered}$

Dessiné par : Bureau d'etudes SNHR

Figure 3.1.1: The equipment of the Mikala 2 well

DOI: 10.31695/IJASRE.2020.33719 


\subsubsection{Well coordinates}

The Mikala 2 well is located in the municipality of Nsele, with coordinates:

- Longitude: $15^{\circ} 31^{\prime} 43.3^{\prime \prime} \mathrm{E}$;

- Latitude: $04^{\circ} 19^{\prime} 23.4^{\prime \prime} \mathrm{S}$;

- $\quad$ Altitude: $314 \mathrm{~m}$

The table below gives the coordinates of different standpipes (BF) in the Mikala network.

Table 3.1.2: the coordinates of the fire hydrant of the Mikala 2 well (SNHR)

$\mathbf{N}^{\circ}$

$\mathrm{BF} 1$

$\mathrm{BF} 2$

BF5

BF4

BF5

BF6

BF11

BF7

BF8

BF9

BF10

\section{LATITUDE}

$4^{\circ} 19^{\prime} 23,2$ ', S

$4^{\circ} 19^{\prime} 18,4$ ' $\mathrm{S}$

$4^{\circ} 19^{\prime} 22^{\prime \prime} \mathrm{S}$

$4^{\circ} 19^{\prime} 20^{\prime \prime} \mathrm{S}$

$4^{\circ} 19^{\prime} 27,1$ ' $\mathrm{S}$

$4^{\circ} 19^{\prime} 25,6$ ' $\mathrm{S}$

$4^{\circ} 19^{\prime} 50^{\prime \prime} \mathrm{S}$

$4^{\circ} 19^{\prime} 14^{\prime \prime} \mathrm{S}$

$4^{\circ} 19^{\prime} 15,9^{\prime \prime} \mathrm{S}$

$4^{\circ} 19^{\prime} 11,5^{\prime}, \mathrm{S}$

$4^{\circ} 19^{\prime} 15,6^{\prime \prime} \mathrm{S}$

\section{LONGITUDE}

$$
15^{\circ} 31^{\prime} 45,2{ }^{\prime \prime} \mathrm{E}
$$$$
15^{\circ} 31^{\prime} 58,1^{\prime \prime} \mathrm{E}
$$$$
15^{\circ} 31^{\prime} 57,6^{\prime}, \mathrm{E}
$$$$
15^{\circ} 31 ' 55,5^{\prime}, \mathrm{E}
$$$$
15^{\circ} 31^{\prime} 56,5^{\prime}, \mathrm{E}
$$$$
15^{\circ} 31 ' 50,2{ }^{\prime}, \mathrm{E}
$$$$
15^{\circ} 31^{\prime} 26,1^{\prime}, \mathrm{E}
$$$$
15^{\circ} 31^{\prime} 40,4^{\prime \prime} \mathrm{E}
$$$$
15^{\circ} 31^{\prime} 44,9^{\prime \prime} \mathrm{E}
$$$$
15^{\circ} 31^{\prime} 45,2 \text { ' } \mathrm{E}
$$

$15^{\circ} 31^{\prime} 55,2{ }^{\prime} \mathrm{E}$
ALTITUDE (m) 305

305

306

304

306

305

305

304

306

306

306 


\subsection{Pumping trials}

A level measurement test was carried out in the Mikala2 well in order to determine the static level of the Mikala2 well before starting pumping. We used a probe. Thus the static level of water in the well is $19.8 \mathrm{~m}$ as shown in the table below.

4.2.1. Level measurement and pumping rate

Before starting pumping, we first measured the water level in the well (static level). The pumping rate is $12 \mathrm{~m} 3 / \mathrm{h}$ and the static level is $19.8 \mathrm{~m}$. Before reaching the steady state after every 15 seconds we measured the following levels:

Table 3.2.1: The pumping test in the Mikala 2 well

\section{Pumping rate $: 12 \mathrm{~m}^{3} / \mathrm{h}$}

$\begin{array}{lll}\text { Time (s) } & \text { Depth }(\mathbf{m}) & \text { Drawdown }(\mathbf{m}) \\ 0 & 19,8 & 0 \\ 15 & 20,2 & 0,4 \\ 30 & 20,24 & 0,44 \\ 45 & 20,25 & 0,45\end{array}$

\subsubsection{The calculation of the transimissivity}

Equation (1) Allows us to determine the transmissivity of the aquifer.

$\delta=\frac{0,183 Q}{T} \log \left(\frac{2,25 T}{S r^{2}}\right)+\frac{0,183 Q}{T} \log (t)$

Indeed, by carrying $\log (\mathrm{t})$ on the abscissa and $\delta$ on the ordinate we obtain a straight line whose angular coefficient is $\frac{0,183 Q}{T}$.

Table 4.2.2: the pumping test in the Mikala 2 well

$\begin{array}{lll}\text { Time }(\mathbf{t}) & \text { Logarithm of time (logt) } & \text { Drawdown } \\ 0 & & 0 \\ 15 & 1,17609126 & 0,4 \\ 30 & 1,47712125 & 0,44 \\ 45 & 1,65321251 & 0,45 \\ \text { Tubing diameter }(\mathbf{m}) & \mathbf{0 , 3 0 4 8} & \\ \text { Tubing radius }(\mathbf{m}) & \mathbf{0 , 1 5 2 4} & \\ \text { Pumping rate }\left(\mathbf{m}^{\mathbf{3}} / \mathbf{s}\right) & \mathbf{0 , 0 0 3 3 3 3 3} & \end{array}$

With the drawdowns on the y-axis and the logarithms of the time on the x-axis, we determined Jacob's line of the Mikala 2 well pumping test. 


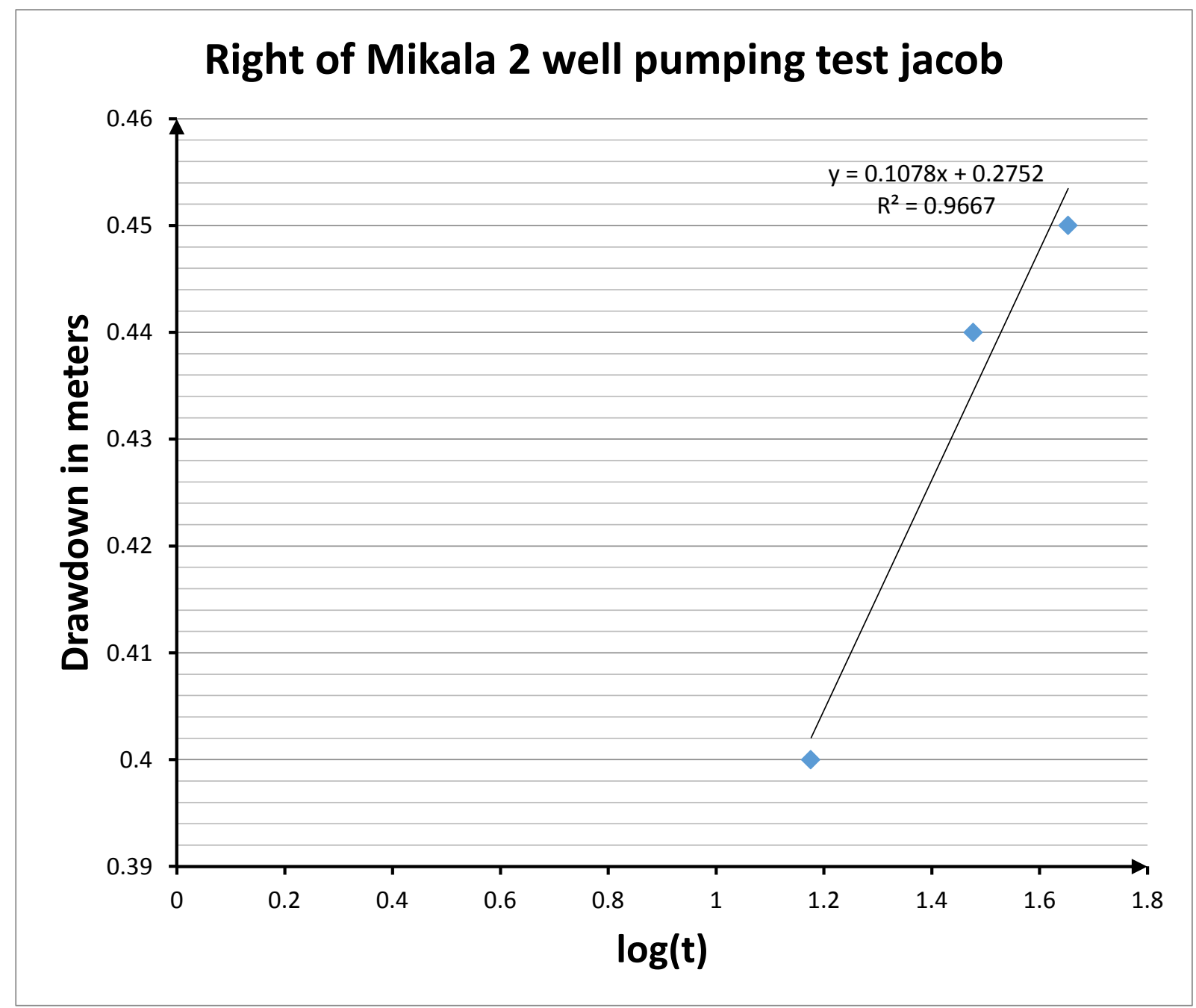

Figure 4.2.1: Jacob's right side of the Mikala 2 well pumping test

The equation of the right of the right of Jacob being:

$Y=0,1078 X+0,2752$

- The angular coefficient

- $\quad m=0,1078$

$\mathbf{m}=\mathbf{0 , 1 0 7 8}$

$\frac{0,183 Q}{T}=m$

$\frac{0,183 Q}{T}=0,1078$

$T=\frac{0,183 Q}{0,1078}$

knowing that the pumping rate is

$$
\begin{aligned}
& 12 \mathrm{~m}^{3} / \mathrm{h}\left(\mathrm{Q}=0,003333 \mathrm{~m}^{3} / \mathrm{s}\right) \\
& \boldsymbol{T}=\frac{\mathbf{0 , 1 8 3} .(\mathbf{0 , 0 0 3 3 3 3})}{\mathbf{0 , 1 0 7 8}}
\end{aligned}
$$


$T=\frac{0,00061}{0,1078}$

$T=0,00565863 \mathrm{~m}^{2} / \mathrm{s}$

$T=20,37 m^{2} / h$

- $\quad$ with : $\boldsymbol{T}=\boldsymbol{k} . \boldsymbol{e}$

k. $e=20,37$

$\boldsymbol{k}=\frac{20,37}{\boldsymbol{e}}$

the thickness of the tablecloth being $39 \mathrm{~m}$

$\boldsymbol{k}=\frac{20,37}{39}$

$k=0,52233481 \mathrm{~m} / \mathrm{h}$

4.2.3. calculating the storage coefficient

4.2.3.1. The determination of the initial time (to)

The equation for Jacob's right of the Mikala 2 well pumping test is $Y=0,1078 X+0,2752$, we can write it

- $\delta=0,1078 \log t+0,2752$

$\boldsymbol{\delta}=\mathbf{0}$

$0=0,1078 \log t_{0}+0,2752$

$0,1078 \log t_{0}=-0,2752$

$\log t_{0}=\frac{-0,2752}{0,1078}$

$t_{0}=10^{(-2,5528757)}$

$t_{0}=0,00279978 s$

4.2.3.2. Determination of the storage coefficient Given Jacob's equation

- $\delta=\frac{0,183 Q}{T} \log (t)+\frac{0,183 Q}{T} \log \frac{2,25 T}{S r^{2}}$

$\delta=\frac{0,183 Q}{T} \log \left(t \frac{2,25 T}{S r^{2}}\right)$

At time $\mathrm{t}_{0}$, the drawdown is zero

$$
\begin{aligned}
& \delta=0 \\
& 0=\frac{0,183 Q}{T} \log \left(t_{0} \frac{2,25 T}{S r^{2}}\right) \\
& 0=\log \left(t_{0} \frac{2,25 T}{S r^{2}}\right) \\
& \log 1=\log \left(t_{0} \frac{2,25 T}{S r^{2}}\right) \\
& 1=t \frac{2,25 T}{S r^{2}} \\
& s=\frac{2,25 T t_{0}}{r^{2}}
\end{aligned}
$$

With: $t_{0}=0,00279978 s ; T=0,00565863 \mathrm{~m}^{2} / \mathrm{s} ; r=0,1524 m$

$S=\frac{2,25 \cdot(0,00279978)(0,00565863)}{0,1524^{2}}$

$S=\frac{0,0000356465}{0,02322576}$

$\mathrm{S}=\mathbf{0 , 0 0 1 5 3 4 7 8 5}$

$S=0,0015$

$\boldsymbol{S}=\mathbf{0}, \mathbf{1 5} \%$

This low value of the storage coefficient confirms that the aquifer is under pressure.

4.2.4. Calculation of diffusivity

Being the ratio of transmissivity to the storage coefficient.

$$
\boldsymbol{\vartheta}=\frac{T}{S}
$$

With: $T=0,00565863 \mathrm{~m}^{2} / \mathrm{s} ; \mathrm{S}=0,15 \%$ 


$$
\begin{aligned}
& \boldsymbol{\vartheta}=\frac{0,00565863}{0,001534785} \\
& \vartheta=3,68691826 \mathrm{~m}^{2} / \mathrm{s}
\end{aligned}
$$

This value of the diffusivity will make it possible to follow in time the field of the hydraulic potential as indicated by the equation (2)

$$
\frac{\partial \varphi}{\partial t}=\frac{K e}{S} \Delta \varphi=\frac{T}{S} \Delta \varphi
$$

It therefore makes it possible to calculate, at each instant, the speed of the variation of the hydraulic potential at any point in the aquifer if we assume that it is homogeneous and isotropic, a very common assumption in hydrogeology.

\subsection{Summary of the results obtained by the pumping test}

The application of the theory seen in chapter 2, to the Mikala 2 aquifer, allowed us to obtain the following hydrogeological characteristics of this aquifer

Transmissivity of the aquifer: $20.37 \mathrm{~m}^{2} \mathrm{~h}$. This is a good value which explains the low drawdown during pumping. This high transmissivity value indicates that the water table can provide up to $50 \mathrm{~m}^{3}$ per hour in steady state. So a single well in this aquifer can supply a population, with standards of 20 liters per person per day applied in DR Congo, of 60 thousand people.

The conductivity is $0.5 \mathrm{~m} / \mathrm{h}$ is also excellent hydraulic conductivity. This is not surprising since all the literature on this aquifer made during the colonial era announces that the aquifer confined to coarse sands is an aquifer with very good hydraulic conductivity.

The value of the storage coefficient of the aquifer confirms its character as a pressurized water table. This confirms its geological configuration presented at the point where it is seen topped with kaolinous sand reputed to be not very permeable to water.

The diffusivity coefficient makes it possible to determine everywhere in this aquifer assumes homogeneous and isotropic, the rate of change over time of the hydraulic potential or of the piezometric surface.

\section{GENERAL CONCLUSION}

The precipitous results found in this work are presented in point 3.6, above.

This constitutes our contribution to the knowledge of the hydro-geological pontentiels of the city of Kinshasa, in general, and of the commune of Nsele, in particular.

We will advise, the Régideso, the National Rural Hydraulic Service as well as the ONG and private companies to search the groundwater in this coarse sand aquifer where the water abounds and which, moreover, protected from any surface contamination by the impermeable layer of kaolin sand which overcomes it. 


\section{REFFERENCES}

1. A.S.A Lateef, Max Fernandez-Alonso, Luc Tack, Damien Delvaux 2010, Geological constraints on urbain sustainability, kinshasa city, Democratic Republic of Congo.

2. Castany, G, 1982, Principes et méthodes de l'hydrogéologie. Dunod Université. Paris

3. Corin, F., and J. Huge, 1948, Coupes géologiques des sondages effectués par le Service Géologique à Léopoldville: Bulletin Service Géologique Congo Belge et Ruanda-Urundi, v. 4, p. 15-53.

4. De Ploey, J., 1965, Quelques aspects de la recherche quaternaire et géomorphologique en Afrique équatoriale: Bulletin de la Société Belge d'Etudes Géographiques, v. 34, p. 159-169.

5. Delevoy, G., 1951, Le Congo forestier, in Encyclopédie du Congo Belge: Bruxelles, Bieleveld, p. 1-14.

6. Devroey, E., and R. Vanderlinden, 1951, Le Bas-Congo artère vitale de notre colonie: Bruxelles, Goemare, 350 p.

7. Egoroff, A., 1956, Carte Géologique de Léopoldville: Bulletin Service Géologique du Congo Belge, v. 6, fasc. 4, p. 1-15.

8. Flouriot, J., R. de Maximy, M. Pain, K. Mbuyi, and X. Van Caillie, 1978, Atlas De Kinshasa. République du Zaïre: Département des travaux publics et de l'aménagement du territoire, Bureau d'études d'aménagements urbains (BEAU), 44 p.

9. Frimmel, H. E., L. Tack, M. S. Basei, A. P. Nutman, and A. Boven, 2006, Provenance and chemostratigraphy of the Neoproterozoic West Congolian Group in Democratic Republic of Congo: Journal of African Earth Sciences, v. 46, p. 221-239, doi:10 .1016/j.jafrearsci.2006.04.010.

10. Lepersonne, J., 1937, Les Terrasses du Fleuve Congo au Stanley Pool: Mémoires Institut Royal Colonial Belge, v. 8, p. 1-67.

11. Mathieu, F.-F., 1912, Observations géologiques faites sur les rives du Congo du Stanley Pool aux Stanley Falls: Annales de la Société Géologique De Belgique, t. XX, C. 61.

12. Nicholson, S. E., 2001, Climatic and environmental change in Africa during the last two centuries: Climate Research, v. 17, p. 123-144, doi: 10.3354/cr017123.

13. Nyong, A., 2005, Impacts of climate change in the tropics: The African experience, in Symposium on Stabilization of Greenhouse Gases, Exeter: A keynote presentation: http://www.stabilisation2005 .com/ (accessed November 20, 2007).

14. Robert, M., 1946, Le Congo physique: Liège, H.Vaillant-Carmanne, 449 p.

15. Robyns, W., 1950, La flore, la végétation in: En cyclopédie du Congo Belge: Bruxelles, Bielveld, p. 390-424.

16. Sekirsky, B., 1956, Les formations mésozoïques et cénozoïques au Sud de Léopoldville anciennement rapportées au Karroo et au Kalahari : Bulletin Service Géologique Congo Belge et Ruanda-Urundi, v. 6, p. 118

17. Tack, L., M.T.D.Wingate, J.-P.Liégeois, M.Fernandez-Alonso, and A. Deblond, 2001, Early Neoproterozoic magmatism (1000-910 Ma) of the Zadinian and Mayumbian groups (Bas-Congo): Onset of Rodinia rifting at the west edge of the Congo craton: Precambrian Research, v. 110, p. 277-306.

18. Van Caillie, X, 1977-1978, La carte géomorphologique et géotechnique de Kinshasa au1/20,000, planche I: République du Zaïre: Département des travaux publics et de l'aménagement du territoire, Bureau d'études d'aménagements urbains (BEAU), scale 1/20,000, 1 sheet,

19. Van Caillie, X., 1987, Notice de présentation de la carte géomorphologique et géotechnique de Kinshasa au 1/20.000: République du Zaïre: Département des travaux publics et de l'aménagement du territoire, Bureau d'études d'aménagements urbains(BEAU), 17 p. 